Please do not remove this page

RMIT

UNIVERSITY

\title{
Investment portfolios and three dimensions of real estate investment: an Australian perspective
}

Heaney, Richard; Higgins, David; Di lorio, Amalia

https://researchrepository.rmit.edu.au/esploro/outputs/9921859175001341/filesAndLinks?institution=61RMIT_INST\&index=null

Heaney, R., Higgins, D., \& Di lorio, A. (2012). Investment portfolios and three dimensions of real estate investment: an Australian perspective. Pacific Rim Property Research Journal, 17(4), 335-354.

https://researchrepository.rmit.edu.au/discovery/fulldisplay/alma9921859175001341/61RMIT_INST:Resea rchRepository

Document Version: Published Version

Repository homepage: https://researchrepository.rmit.edu.au

(C) 2012 Pacific Rim Real Estate Society

Downloaded On 2023/04/26 17:56:31 +1000 
Thank you for downloading this document from the RMIT Research Repository.

The RMIT Research Repository is an open access database showcasing the research outputs of RMIT University researchers.

RMIT Research Repository: http://researchbank.rmit.edu.au/

\section{Citation:}

Heaney, R, Higgins, D and Di lorio, A 2012, 'Investment portfolios and three dimensions of real estate investment: an Australian perspective', Pacific Rim Property Research Journal, vol. 17, no. 4, pp. 335-354.

See this record in the RMIT Research Repository at:

http://researchbank.rmit.edu.au/view/rmit:18656

Version: Published Version

Copyright Statement: (c) 2012 Pacific Rim Real Estate Society

Link to Published Version: 


\title{
INVESTMENT PORTFOLIOS AND THREE DIMENSIONS OF REAL ESTATE INVESTMENT: AN AUSTRALIAN PERSPECTIVE
}

\author{
RICHARD HEANEY \\ University of Western Australia \\ DAVID HIGGINS and AMALIA DI IORIO \\ RMIT University
}

\begin{abstract}
Real estate offers a range of investment alternatives for mutual funds including residential real estate, commercial real estate and units in listed real estate investment trists (REITS). Oum quarterly total return data spans the period from the $3^{\text {rd }}$ quarter 1986 to the $3^{\text {rd }}$ quarter 2009 using various combinations of the Australian All Ordinaries share price index and these three classes of real estate investment. Comparison of Sharpe and Sortino (downside risk) measures across a range of portfolios suggest that diversification benefits may be achieved through diversifying into real estate investment, particularly direct investment in residential real estate, given an initial exposure to the equity market.
\end{abstract}

Key words: real estate, diversified portfolio performance, smoothed real estate returns

\section{INTRODUCTION}

While individuals may see real estate as a safe asset for longer-term investment, this attraction to real estate is not so evident with professionally run pension funds, with real estate investment accounting for around $10 \%$ of UK and $5 \%$ of US portfolio investments (Blake et al 1999, HudsonWilson et al 2003). Australian superannuation funds follow the UK practise with an average superannuation default strategy allocation to real estate assets of 9.5\% (APRA 2012), accounting for about $\$ 35$ billion of the $\$ 376$ billion falling within the APRA default strategy survey. This compares with an allocation of $\$ 197$ billion $(52 \%)$ to Australian and International shares. In this paper we focus on three broad classes of real estate, residential real estate, commercial real estate and exchange traded REITs and we explore the impact a real estate investment might have on a well-diversified all Australian equity investment portfolio.

Real estate investments can be split into three broad classes, residential real estate, commercial real estate and real estate trusts (both listed and unlisted). While real estate is often viewed as one asset class, the results in this paper suggest that there are important differences between these three real estate classifications in terms of expected returns, volatility and covariance with the share market. The residential real estate market is quite different from the commercial real estate market. Residential properties tend to be relatively small assets traded irregularly over long periods of time. Both buyers and sellers rely heavily on real estate agents in their decisions and much of the market activity is explained by changes in individual's needs: employment, divorce, death, etc. The Australian commercial real estate market is characterised by irregular trading in a limited number of fairly large heterogeneous properties such as office buildings or retail properties. This market is characterised by a small number of skilled traders and investors. The third class consist of real estate investment trusts, commonly called REITs. These entities provide access to real estate related assets without the need to physically own and manage these assets. Unit holders in a REIT are much like shareholders and, indeed, the units in listed REITs can be traded on the stock exchange. These trusts commonly hold new and existing mortgages, mortgage backed securities and commercial real estate. Some REITs specialise in particular types of real estate like shopping complexes, for example. 
Published Australian real estate research generally focuses on describing the market (Higgins 2007), modelling the determinants of real house prices (Abelson et al 2005, Bodman and Crosby 2003), surveying Australian fund manager attitudes to real estate investment funds (Keng 2004) and assessing the perfornance of Australian listed REITs (Higgins and $\mathrm{Ng} 2009$ ). There is little published analysis of the diversification benefits arising from investment in Australian real estate, especially residential real estate, with the exception of recent work by Lee (2008) and Newell et al (2011). Both Lee (2008) and Newell et al (2011) report measures of risk-adjusted return for various Australian asset classes as well as correlations between the returns earned by these asset classes, though Newell et al (2011) do explore time variation in volatility and correlation over their sample period, 1995 to 2009 . They both note relatively poor performance with REIT based investments and stronger performance with direct investment in property. There is little discussion of the actual impact on equity portfolio returns of investing in real estate, which is the main topic of this paper.

The benefit of investing in residential real estate is analysed in three recent papers. Lee (2008) finds that Australian residential real estate performs well in a risk adjusted return sense and exhibits low correlation with the major asset classes available to investors. Masron and Fereidouni (2010) conduct a similar analysis for Iranian investors, with results that are favourable to residential real estate investment. Jud et al (2006) focus on USA residential housing investment with similar findings. They also analyse the impact of residential real estate on portfolio performance where the portfolio also includes some of the major asset classes available to individual investors including equities, bonds and bilis. They find that residential real estate is included in the majority of their minimum risk portfolios. It is also found that higher tax bracket individuals generally prefer residential real estate investment and housing investment performance shows considerable variation across geographical sectors of the USA. Our data is not as rich as that of Jud et al (2006) as our data applies to Australia generally but it does cover a longer period (1986 to 2010) with a focus on equities and real estate. Our data period is also more than double that of Lee (2008), from 1996 to 2007, or Masron and Fereidouni (2010), 2001 to 2008. Further, we extend the work of Lee (2008) and Masron and Fereidouni (2010) through our analysis of the impact on an equity portfolio of investing in our three classes of commercial real estate, residential real estate and/or REITs.

Chiang and Lee (2007) and Lee et al (2007) also analyse the diversification benefits of REITs relative to private real estate within a portfolio context using spanning tests. They find that private real estate investment tends to dominate investment in REITs. Both studies include a wide range of asset classes with the Chiang and Lee (2007) paper being based on US data and the Lee et al (2007) paper drawing on data from Asia, Europe and the US. The latter paper finds that diversification into international real estate markets needs some care, particularly for REITs, as the relative performance of this asset class varies over time. While the spanning tests are relied upon in their paper, we focus on the performance of more concentrated portfolios consisting of equity and real estate.

The main contribution of this paper is in the comparison of the three classes of real estate investment with analysis of the impact of direct (residential and commercial real estate) and indirect real estate returns on the performance of a well-diversified equity portfolio in an Australian setting using a relatively long series of quarterly data. We first analyse the links that exist between listed REIT, residential real estate and commercial real estate returns. We then analyse the impact of real estate investment on portfolio performance where the portfolio consists of a well-diversified share portfolio and real estate. A discussion of estimation issues is provided in the following section, then data is described and the results of analysis are reported with conclusions drawn in the final section. 


\section{ESTIMATION ISSUES}

Investors may hold real estate as a direct investment or an indirect investment and we have access to data on two direct investment classes, residential real estate and commercial real estate. Direct real estate investment market is characterised by thin trading and appraisal based valuation which can generate smoothed price series. For example price indices calculated for illiquid markets tend to consist of complex combinations of stale and fresh prices because the underlying assets are not traded on a regular basis. Inclusion of stale prices in a price index results is an artificially smooth price series with calculated returns exhibiting serial correlation. Similarly, when the underlying assets are valued using some form of appraisal system, as happens with commercial property, there is a tendency for the appraisal value to be anchored on previous valuations as well as on current information and this also leads to artificially smooth prices and serial correlation in returns. This smoothing can have a considerable impact on the time series behaviour of real estate prices and risk adjusted performance measures, with recent studies reporting US cirect real estate return volatility (3.4\% pa), about half the volatility calculated for REITs (7\%-8\%) (Giliberto 1993, Giliberto 2003). Sinilar problems occur for residential properties which, while being more homogeneous, are still quite thinly traded and this also results in smoothing of indices that reflect general changes in the value of residential real estate. It is important that this problem is corrected in some way if valid calculation of test statistics or comparison of risk adjusted performance measures is to be achieved.

Corrections for smoothing in direct real estate investment include more careful index calculation (Geltner and Goetzmann 2000), simple statistical adjustment (Chiang and Lee 2007, Cho et al 2003, Georgiev et al 2003, Lee 2008, MacGregor and Nanthakumaran 1992, Newell and MacFarlane 1996) and increasing the return estimation period to minimise the impact of smoothing (Byme and Lee 1995). Index recalculation requires access to individual real estate prices that make up the underlying real estate index. This alternative is not possible given the nature of the data used in this study. We rely on statistical adjustment in this study to gain a more precise indication of the benefit of direct investment in Australian real estate, though not all studies adjust their data for these problems (Masron and Fereidouni 2010, Newell et al 2011). Our results are reported both with and without adjustment for smoothing for both residential real estate and commercial real estate returns.

Indirect investment in listed real estate investment trusts (REITs) and real estate mutual funds (REMF - in Australia these funds are commonly called real estate managed funds) offer more liquid investment vehicles (Feldman 2003) though research concerning the diversification potential of these securities is inconclusive, with both support for (Brounen and Eichholtz 2003) and criticism of (Byrne and Lee 1995, Chaing and Lee 2007, Clayton and MacKinnon 2001, Georgiev et al 2003, Lee et al 2007) these real estate investment vehicles. Indices used to capture the performance of indirect investment in listed REITs are observed to suffer from microstructure effects (Brounen and Eichholtz 2003) in that they tend to track share market returns more closely than the underlying real estate that they are composed of. One way to remove the share market component of the return to REITs is to calculate hedged quarterly returns which by their nature are orthogonal to the share market (Brounen and Eichholtz 2003, Lee et al 2007). We report results for both REIT index returns and hedged REIT (orthogonalised with respect to the equity market) returns in the analysis that follows.

\section{DATA DESCRIPTION}

The data used in this study consist of quarterly returns calculated for the Australian share market as well as for three real estate investment classes (listed REIT, commercial real estate and residential real estate) over the period from December 1985 through to September 2009. The returns reflect both capital gains and income. The final data set used in analysis excludes the first few quarters to 
allow for adjusted return estimation giving a final sample period of September 1986 through to September 2009.

The Australia Securities Exchange All Ordinaries Share Price Accumulation Index, $S P I_{t}$, is a value weighted index that reflects returns to a broad share market portfolio. The index is adjusted for both capitalisation changes and dividends. In using this index we assume the investor is welldiversified with respect to the equity market. This is important because a key objective of this paper is to assess the diversification benefits gained from diversifying an equity only portfolio to include different classes of real estate investment. The Australian share market return is calculated as: $\ldots$

$$
r_{t}^{S P I}=\frac{S P I_{\tau}}{S P I_{t-1}}-1
$$

The REIT index used in this study is the Australian listed real estate investment trust sub-index from the ASX300 share price index, $R E I T_{5}$. This index is a value weighted index of the larger REITs traded on the Australian Securities Exchange. The return on REITs is calculated as:

$$
r_{t}^{S P I}=\frac{R E I T_{t}}{R E I T_{t-1}}-1
$$

Returns to direct commercial real estate are calculated using the IPD/PCA Property Investors Digest Series (Composite) Index, IPD/PCA. (http://www1.ipd.com/Pages/default.aspx). This index includes both income and capital gains earned on a portfolio of direct commercial real estate investments. As of March 2012 the index covered 1,700 assets valued at $\$ 130$ billion. It is arguably the most comprehensive Australian commercial real estate index available at present. As indicated above, this series relies on appraisal values for valuation of illiquid assets in periods when actual transactions do not occur and so the calculated return series will tend to be smoothed over time. Adjustment for this smoothing effect is discussed below. The return is calculated as:

$$
r_{t}^{R \operatorname{con} n}=\frac{I P D / P C A_{t}}{I P D / P C A_{t-1}}-1
$$

There is no total return index available for direct investment in Australian residential real estate over the period of this study and so we construct a total return index for residential real estate using data provided by the Australian Bureau of Statistics. The Australian house price index, HPI, provides a measure of the capital gain to Australian residential real estate (ABS catalogue no. 6416). This index covers transactions in detached residential dwellings on their own block of land regardless of age (i.e. including new houses sold as a house/land package as well as second-hand houses). The quarterly rental return component, $H R I_{t}$, is obtained from the housing rental index, which is a component of the consumer price inflation index (ABS catalogue no. 6401). Residential real estate acquired for investment are generally managed and so we need to adjust the rental return for the cost of managing the property. We set rental management costs at $12 \%$ of rental eamings following Australian Taxation Office statistics for indivicual rental income and deductions on private real estate in the tax year 2006-07. The choice of $12 \%$ for outgoings is compatible with local market evidence. Smoothing problems also exist for this data because residential property sales do not occur smoothly over time and our chosen index for capital gains will only capture the sales that occur. Thus, the return on Australian residential real estate is calculated for each quarter as:

$$
r_{t}^{R r s}=\frac{H P I_{t}+H R I_{t}(1-0.12)}{H P I_{t-1}}-1
$$




\section{De-Smoothing Commercial Real Estate and Residential Real Estate Returns}

While residential real estate returns are based on broad movements in residential housing price and rent, commercial real estate returns are based on appraisal values. Both residential real estate and commercial real estate are illiquid and their return time series exhibit serial correlation. One adjustment commonly used to remove smoothing in the quoted indices is based on the assumption that the smoothed data follows an autoregressive process. Say that the data follow an AR(3) process:

$$
r_{E}^{D D}=\alpha+\beta_{1} r_{t-1}^{D P}+\beta_{2} r_{t-2}^{D F}+\beta_{3} r_{*-3}^{D E}+\varepsilon_{t}
$$

where:

$r_{:}^{D P}=$ quoted return on direct real estate investment at time $t$

$\varepsilon_{t}=$ residual term at time $t$

The smoothed return observed at time $t$ is modelled as a weighted average of prior period smoothed returns and current period underlying return where the weights sum to one:

$$
r_{t}^{D F}=\left(1-\beta_{1}-\beta_{2}-\beta_{3}\right) r_{t}^{D}+\beta_{1} r_{t-1}^{D F}+\beta_{2} r_{t-2}^{D F} \div \beta_{3} r_{t-3}^{D P}
$$

where:

$$
r_{t}^{U}=\text { underlying (adjusted or corrected) return on direct real estate index at time } t .
$$

The equation can be rearranged to provide an estimate of the underlying or adjusted return for direct investment in real estate:

$$
r_{t}^{V}=\frac{1}{\varphi} r_{i}^{D F}+\frac{\beta_{1}}{\varphi} r_{i-1}^{D P} \div \frac{\beta_{2}}{\varphi} r_{t-2}^{D P}+\frac{\beta_{3}}{\varphi} r_{i-3}^{D P}
$$

where:

$$
\varphi=\left(1-\beta_{1}-\beta_{2}-\beta_{3}\right)
$$

Generally an AR(1) model is assumed for this correction (Lee 2008) though there has been little analysis of this question using Australian data. We fit a number of autoregressive models to the direct investment indices and the results are reported in Table 1. An AR(8) model is initially fitted to the data. The model is then re-estimated excluding the statistically insignificant coefficients, with likelihood ratio tests and $t$-tests used to identify an appropriate restricted model. This approach to model lag choice results in an AR(3) model for the direct commercial real estate data and an $\mathrm{AR}(1,3)$ model with lags at 1 and 3 for the residential real estate data (likelihood ratio tests statistics on the restrictions imposed with these models of 1.27 and 5.09 respectively). Following the prior literature, the model was further restricted to an AR(1) model. The likelihood ratio statistics (LR test) indicate that this restriction should be rejected as the statistics are statistically significant, with a likelihood ratio statistic of 31.82 for the commercial real estate index and 4.34 for the residential real estate model. As a result $A R(1)$ models are not used in the analysis though the price series from these alternative models are graphed in Figure 1, where the real estate price time series are adjusted to have the same base value of 100 in 1986. 


\begin{tabular}{|c|c|c|c|c|c|c|}
\hline Variable names & $R$ Com & $R C o m$ & $R$ Com & RRes & RRes & RRes \\
\hline Constant & $\begin{array}{r}0.0237^{*} \\
(3.62)\end{array}$ & $\begin{array}{r}0.0241^{*} \\
(3.50)\end{array}$ & $\begin{array}{r}0.0215^{*} \\
(1.69)\end{array}$ & $\begin{array}{r}0.0325^{*} \\
(6.83)\end{array}$ & $\begin{array}{r}0.0323^{*} \\
(7.56)\end{array}$ & $\begin{array}{r}0.0324^{*} \\
(5.86)\end{array}$ \\
\hline $\begin{array}{l}\text { AR model lag } \\
\text { coefficients }\end{array}$ & & & & & & \\
\hline Lag 1 & $\begin{array}{r}0.9533^{*} \\
(4.43)\end{array}$ & $\begin{array}{r}0.9993^{*} \\
(6.15)\end{array}$ & $\begin{array}{r}0.9430^{*} \\
(33.95)\end{array}$ & $\begin{array}{r}0.7931^{*} \\
(6.76)\end{array}$ & $\begin{array}{r}0.7769^{*} \\
(8.81)\end{array}$ & $\begin{array}{r}0.6966^{*} \\
(11.82)\end{array}$ \\
\hline Lag 2 & $\begin{array}{r}0.5005^{*} \\
(2.07)\end{array}$ & $\begin{array}{r}0.4417^{*} \\
(2.44)\end{array}$ & & $\begin{array}{r}0.0445 \\
(0.22)\end{array}$ & & \\
\hline Lag 3 & $\begin{array}{r}-0.5178^{*} \\
(-2.24)\end{array}$ & $\begin{array}{r}-0.5480^{*} \\
(-7.55)\end{array}$ & & $\begin{array}{r}-0.3566^{*} \\
(-2.02)\end{array}$ & $\begin{array}{r}-0.1732^{*} \\
(-2.09)\end{array}$ & \\
\hline $\operatorname{Lag} 4$ & $\begin{array}{r}-0.1053 \\
(-0.43)\end{array}$ & & & $\begin{array}{r}0.2348 \\
(1.55)\end{array}$ & & \\
\hline Lag 5 & $\begin{array}{r}0.0870 \\
(0.37)\end{array}$ & & & $\begin{array}{r}-0.0079 \\
(-0.04)\end{array}$ & & \\
\hline Lag 6 & $\begin{array}{r}-0.0302 \\
(-0.14)\end{array}$ & & & $\begin{array}{r}-0.0775 \\
(-0.54)\end{array}$ & & \\
\hline Lag 7 & $\begin{array}{r}0.0472 \\
(0.20)\end{array}$ & & & $\begin{array}{r}-0.0932 \\
(-0.57)\end{array}$ & & \\
\hline $\operatorname{Lag} 8$ & $\begin{array}{r}-0.0576 \\
(-0.31)\end{array}$ & & & $\begin{array}{r}0.0756 \\
(0.51)\end{array}$ & & \\
\hline $\begin{array}{l}\text { Wald test } \\
\text { (full model) }\end{array}$ & $1812.27^{*}$ & $1814.11^{\text {* }}$ & $1152.38^{*}$ & $101.71^{*}$ & $115.26^{*}$ & $139.81^{*}$ \\
\hline $\begin{array}{l}\text { LR test of } \\
\text { restrictions }\end{array}$ & & 1.27 & $31.82 *$ & & 5.09 & $4.34 *$ \\
\hline No. of restrictions & & 5 & 2 & & 6 & 1 \\
\hline
\end{tabular}

Note: This Table reports the estimated coefficients from fitting various auto regression models to the direct real estate investment asset classes, RCom and RRes returns. RCom is the unadjusted return for commercial real estate. RRes is the unadjusted return for residential real estate. The Wald test is a test for statistical significance of the estimated model. LR test is a test of the restrictions imposed in arriving at the model of interest, 8 lags to 3 lags and from 3 lags to 1 lag. No of restrictions refers to the number of restrictions implicit in the LR test. * ${ }^{(+)}$statistically significant at the $5 \%(10 \%)$ level of significance.

\section{Auto Regression Models for Direct Investment Returns Source: Authors \\ Table 1}

The impact of model choice is particularly evident in Figure 1 for the global funancial crisis, where an AR(1) based model generates relatively extreme price movements in this period. Table 1 provides further evidence of the variation between the different time series models used to capture serial correlation in the original data. 


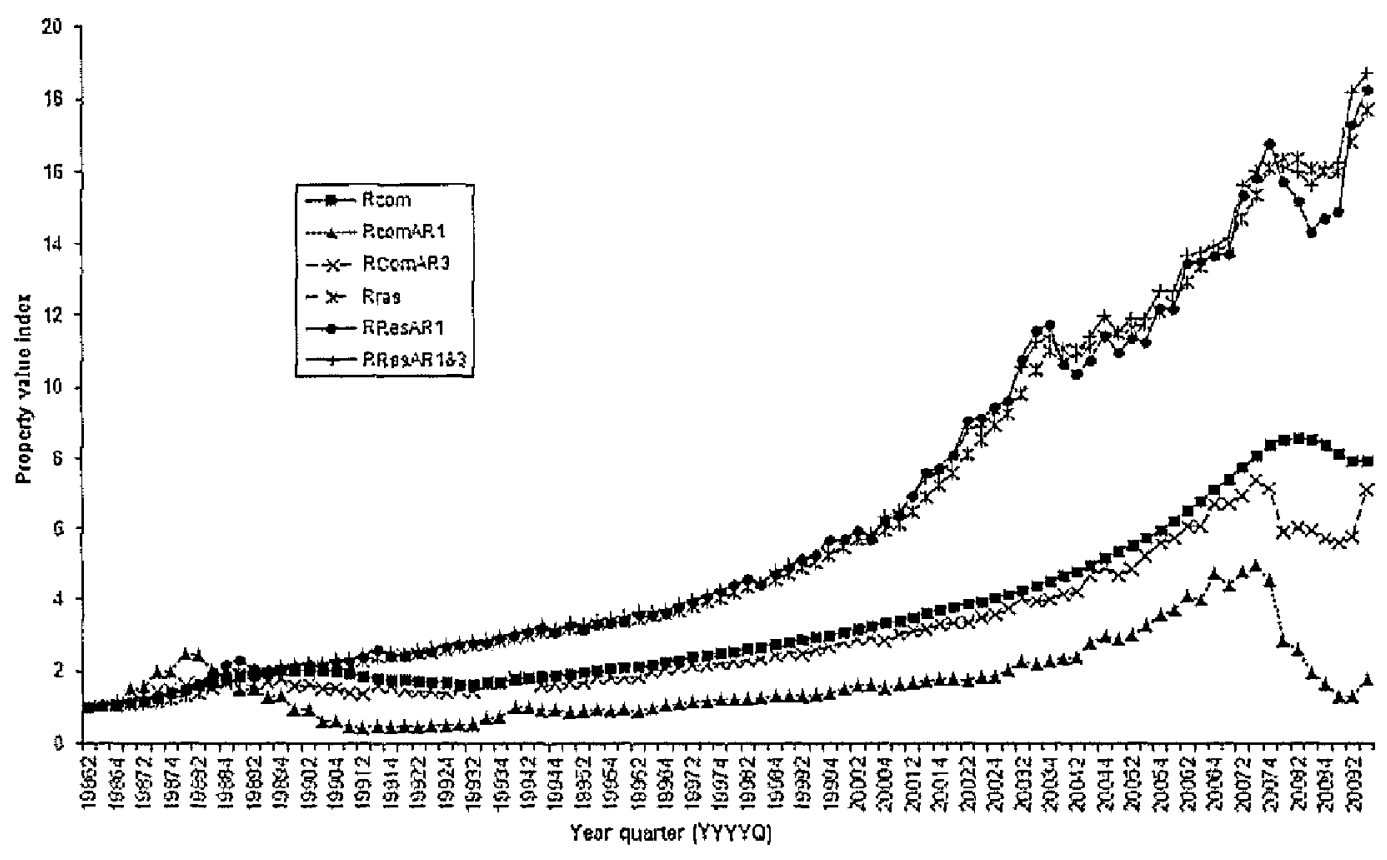

\section{Comparison of Initial and Adjusted Direct Real Estate Investment Indices Source: Authors \\ Figure 1}

The unsmoothed data used in the analysis of commercial real estate investment returns is based on an $\operatorname{AR}(3)$ model while an $\operatorname{AR}(1,3)$ model is used in unsmoothing the residential real estate investment returns. Results are reported for both smoothed and unsmoothed commercial real estate returns or residential real estate returns in the following sections.

\section{Hedged (Orthogonal) REIT Returns}

The ASX S\&P 300 REIT index provides a measure of retums to listed Australian real estate investment trusts. This value weighted index consists of the REITs in the S\&P/ASX 300 share price index and reflects the performance attained by a well-diversified portfolio of larger REITs traded on the Australian Stock Exchange. It has been argued in the literature that listed real estate trust data exhibits excessive volatility, driven more by general share market movements than by the underlying real estate assets held by the trust. A common adjustment for this effect is to remove the broad share market movements using a hedged portfolio. The hedge ratio is obtained in the usual way by regressing real estate trust index returns on a share market index.

$$
r_{ \pm}^{R E I T}=\phi+\omega r_{t}^{S P Y}+n_{t}
$$

where:

$$
\begin{aligned}
& r_{t}^{A} R E I T=\text { return on REIT index at time } t \\
& r_{t}^{S E t}=\text { retum on All Ordinaries Share Price Index at time } t \\
& \eta_{t}=\text { residual term at time } t
\end{aligned}
$$

The hedged (orthogonalised) REIT portfolio return is defined as:

$$
r_{t}^{E}=r_{t}^{R E T T}-\omega r_{t}^{S P t}
$$


This adjustment removes the variation in the REIT returns explained by broad share market movements. In effect the hedged REIT returns are orthogonal to the equity market and should reflect that component of REIT returns that is unique to the property underlying the REITs. The resulting hedged return series is considerably less volatile than the share market, as well as being uncorrelated with the share market by construction (see the zero correlation coefficient for the Rreit(h) and Rallord series in Table 4 below). We report results from analysis for both the hedged and unhedged REIT returns.

\section{Summary Statistics}

The,descriptive statistics are reported in Table 2.

\begin{tabular}{l|ccccc}
\hline & Average & Median & $\begin{array}{c}\text { Standard } \\
\text { Deviation }\end{array}$ & Maximum & Minimum \\
\hline RCom & 0.0228 & 0.0252 & 0.0230 & 0.0762 & -0.0323 \\
RCom, AR(1) & 0.0152 & 0.0189 & 0.1328 & 0.3807 & -0.3779 \\
RCom, AR(3) & 0.0231 & 0.0252 & 0.0598 & 0.2298 & -0.1723 \\
RRes & 0.0317 & 0.0284 & 0.0222 & 0.1116 & -0.0177 \\
RRes, AR(1) & 0.0330 & 0.0341 & 0.0509 & 0.2025 & -0.0999 \\
RRes, AR(1\&3) & 0.0327 & 0.0320 & 0.0381 & 0.1696 & -0.0564 \\
Rreit & 0.0206 & 0.0381 & 0.0913 & 0.2684 & -0.4040 \\
Rreit(h) & 0.0040 & 0.0152 & 0.0671 & 0.1394 & -0.2647 \\
Rallord & 0.0251 & 0.0387 & 0.0941 & 0.2470 & -0.5219 \\
BAB90 & 0.0198 & 0.0152 & 0.0101 & 0.0471 & 0.0104 \\
\hline
\end{tabular}

Note: RCom is the unadjusted return on commercial real estate with $R C O m \operatorname{AR}(1)$ and RCom AR(3) being the unsmoothed returns to commercial real estate. RRes is the unadjusted return residential real estate with RRes AR(1) and RRes $A R(1 \& 3)$ being the unsmoothed returns to residential real estate. Rreit is the unadjusted return on Australian REITs with Rreit(h) being the hedged returns to REITs. BAB90 is the 90 day bank accepted bill rate.

\section{Investment Class Performance: Descriptive Statistics Source: Authors \\ Table 2}

Table 2 includes descriptive statistics for the returns to the share market, returns to the three real estate investment classes and the short-term interest rate, the 90 day bank accepted bill rate (BAB90). Descriptive statistics are reported for unsmoothed commercial and residential real estate returns using both the $A R(1)$ model and the model fit to the data, AR(3) for commercial real estate and $A R(1 \& 3)$ for residential real estate. The unsmoothed data is considerably more volatile. The standard deviation in quarterly returns for direct investment in commercial real estate increases from $2.3 \%$ per quarter for RCom to $5.98 \%$ per quarter for RCom, AR(3) and the standard deviation in quarterly returns for direct investment in residential real estate increases from $2.22 \%$ per quarter for $\mathrm{RRes}$ to $3.81 \%$ per quarter for $\operatorname{RRes}, \mathrm{AR}(1 \& 3)$. In both cases the standard deviation for the adjusted series is essentially double that of the unadjusted series, consistent with the results reported by Georgiev et al (2003) for their US NCREIF data. The mean returns for the smoothed and unsmoothed direct real estate investment indices range from $1.52 \%$ to $3.27 \%$ per quarter.

Table 2 also illustrates that the volatility of the hedged ASX300 REIT index returns $(0.0671$ per quarter for Rreit(h)) is somewhat lower than that of the unhedged index $(0.0913$ per quarter for Rreit), consistent with the hedging adjustment used to remove general equity market volatility. The reduction in standard deviation of around $30 \%$ is somewhat greater than that noted by Georgiev et al (2003) for the NAREIT hedged returns. The volatility for adjusted commercial real estate and for 
hedged REITs is approximately $6 \%$ per quarter while the volatility for the adjusted residential real estate is around $4 \%$ per quarter.

The All Ordinaries share price index return volatility is 0.0941 per quarter, which is fairly close to the volatility of the unadjusted REIT return series $(0.0913$ per quarter). The 90 -day bank accepted bill yields have average return of 0.0198 per quarter with volatility of 0.0101 per quarter These yieids are used in calculation of risk free rate adjusted rates of return which are used in calculation of the Sharpe ratios and the Sortino ratios. Serial correlation coefficients are reported in Table 3 for these series.

\begin{tabular}{l|cllrrr}
\hline & $\rho 1$ & $\rho 2$ & $\rho 3$ & $\rho 4$ & $\rho 8$ & $\rho 10$ \\
\hline RCom & $0.94^{*}$ & $0.88^{*}$ & $0.77^{*}$ & $0.64^{*}$ & 0.06 & -0.22 \\
RCom, AR(1) & 0.11 & $0.48^{*}$ & 0.05 & 0.13 & -0.05 & -0.32 \\
RCom, AR(3) & -0.03 & 0.03 & 0.03 & -0.07 & 0.16 & -0.13 \\
RRes & $0.72^{*}$ & $0.46^{*}$ & 0.20 & 0.12 & -0.11 & -0.07 \\
RRes, AR(1) & 0.12 & 0.11 & -0.23 & 0.02 & 0.09 & 0.16 \\
RRes, & & & & & & \\
AR(I\&3) & 0.05 & 0.06 & -0.14 & 0.13 & 0.14 & 0.17 \\
Rreit & 0.23 & -0.04 & 0.15 & 0.13 & -0.01 & -0.19 \\
Rreit(h) & 0.12 & -0.08 & 0.18 & 0.17 & 0.04 & -0.19 \\
Rallord & -0.07 & -0.01 & 0.00 & -0.15 & 0.12 & -0.02 \\
\hline
\end{tabular}

Note: RCom is the unadjusted return on commercial real estate with RCom AR(I) and RCom $A R(3)$ being the unsmoothed returns to commercial real estate. RRes is the unadjusted return residential real estate with RRes AR(1) and RRes AR(1\&3) being the unsmoothed returns to residential real estate. Rreit is the unadjusted return on Australian REITs with Rreit(h) being the hedged returns to REITs. Rallord is the return on the Australian All Ordinaries Share Price index. ${ }^{*}(+)$ statistically significant at the $5 \%(10 \%)$ level of significance.

\section{Investment Class Performance: Serial Correlation Coefficients Source: Authors \\ Table 3}

Serial correlation is evident in the original direct real estate investment returns (Table 3), consistent with the existence of smoothing effects while the unsmoothed real estate returns show no evidence of statistically significant serial correlation. Further, there is no evidence of statistically significant serial correlation in the share market based index returns for our sample period. Pearson correlation coefficients are reported in Table 4.

There is evidence of statistically significant correlation between the direct investment asset class returns and between commercial direct investment returns and REIT returns in Table 4, Yet, the REIT returns are not significantly correlated with residential real estate returns. The unadjusted and hedged REIT returns are correlated. Further, the unsmoothed direct commercial real estate index returns are positively correlated with REIT retums and share market retums. The correlation coefficients between quarterly returns for unsmoothed residential real estate returns and share market returns are generally small (less than 0.40 ) suggesting the possibility of diversification gains from investment across these asset classes consistent with the work of Lee (2008) and Masron and Fereidouni (2010). 


\begin{tabular}{l|cccccccc}
\hline & \multicolumn{9}{c}{ RCom } & RCom & \multicolumn{2}{c}{ RRes } & RRes \\
& RCom & AR(1) & AR(3) & RRes & AR(1) & AR (1\&3) & Rreit & Rreit(h) \\
\hline RCom, AR(1) & $0.34^{*}$ & & & & & & & \\
RCom, AR(3) & $0.29^{*}$ & $0.85^{*}$ & & & & & & \\
RRes & $0.42^{*}$ & 0.10 & 0.10 & & & & & \\
RRes, AR(1) & $0.21^{*}$ & 0.16 & 0.11 & $0.71^{*}$ & & & & \\
RRes, AR(1\&3) & $0.23^{*}$ & 0.11 & 0.08 & $0.69^{*}$ & $0.98^{*}$ & & & \\
Rreit, & 0.13 & $0.42^{*}$ & $0.41^{*}$ & 0.11 & 0.04 & 0.01 & & \\
Rreit(h) & 0.11 & $0.26^{*}$ & $0.25^{*}$ & 0.16 & 0.07 & 0.05 & $0.73^{*}$ & \\
Rallord & 0.07 & $0.34^{*}$ & $0.33^{*}$ & -0.01 & -0.02 & -0.05 & $0.68^{*}$ & 0.00 \\
\hline
\end{tabular}

Note: RCom is the unadjusted retum on commercial real estate with RCom AR(1) and RCom AR(3) being the unsmoothed returns to commercial real estate. RRes is the unadjusted return residential real estate with RRes AR(1) and RRes AR(1\&3) being the unsmoothed returns to residential real estate. Rreit is the unadjusted return on Australian REITs with Rreit(h) being the hedged returns to REITs. Rallord is the return on the Australian All Ordinaries Share Price index. ${ }^{*}(+)$ statistically significant at the 5\% (10\%) level of significance.

\title{
Investment Class Performance: Pearson Correlation Coefficients Source: Authors
}

Table 4

\begin{abstract}
ANALYSIS
The performance of direct investment in commercial and residential real estate, as well as the indirect investment in listed REITs, is compared in this section. The comparisons are based on risk free rate adjusted returns. Separate results are reported for adjusted (unsmoothed or hedged) real estate returns as well as for unadjusted real estate returns. As well as reporting mean and standard deviation of the risk free rate adjusted returns we also report two rneasures of risk adjusted performance, the Sharpe ratio and the Sortino ratio. These statistics are calculated using all 93 available quarterly observations for the period from $3^{\text {td }}$ quarter 1986 to the $3^{\text {td }}$ quarter 2009 . Subperiod analysis similarly is based on all available data for the sub-period.
\end{abstract}

The Sharpe ratio captures the excess return per unit of total risk and is applied to both adjusted and unadjusted returns. Given $R_{p}$ is the real estate portfolio return, $R_{f}$ is 90 -day bank accepted bill yield, $R_{p}-R_{f}$ is the risk free rate adjusted return and $R_{p}-R_{f}$ is the average risk free rate adjusted return, this ratio is defined as:

$$
\text { Sharpe ratio }=\frac{\overline{R_{p}-R_{f}}}{\sigma\left(R_{p}-R_{f}\right)}
$$

The Sortino ratio (Chaudhry and Johnson 2008, Sortino and Price 1994) provides the second performance measure and this measure focuses on downside risk relative to return. This ratio scales average return in excess of a benchmark (the risk free rate in the following analysis) with a measure of downside risk, the second lower partial moment. It is defined as:

$$
\text { Sortino ratio }=\frac{\bar{\alpha}}{D D}
$$

where the downside deviation (DD) is defined as: 


$$
D D=\sqrt{\frac{I}{N} \sum_{t=1}^{N}\left(R_{t}-R_{f t}\right)^{2} I\left(R_{t}<R_{f t}\right)}
$$

where $I\left(R_{t}<R_{f t}\right)$ is an indicator variable with a value of one if the expression in parentheses is true and zero otherwise.

The term $\bar{\alpha}$ is defined as:

$$
\bar{\alpha}=\frac{1}{N} \sum_{t=1}^{N}\left(R_{t}-R_{f t}\right)\left(R_{t}<R_{f t}\right)
$$

Initial analysis is undertaken from the viewpoint of creating a real estate portfolio. There are seven real estate portfolios included in analysis with $100 \%$ investment in each of the three real estate asset classes, three pairs of real estate asset classes with $50 \%$ investment in each asset class and, finally, a portfolio including each of the three real estate asset classes with one-third investment in each of the three real estate asset classes. The results from this analysis are reported below. Analysis is then widened to deal with the choice that a diversified equity investor might face when looking to diversify into real estate in the section thereafter. While we use the same set of seven real estate portfolios we initially limit the real estate investment to either $5 \%$ or $10 \%$ of the portfolio, consistent with mean institutional investor real estate investment patterns reported in the literature (APRA 2012, Blake et al 1999, Hudson-Wilson et al 2003). The section thereafter is then devoted to analysis of short-selling constrained Markowitz optimal portfolios of equity and real estate to further explore the impact of equity constraints and data adjusted on the choice of the three real estate classes discussed in this paper.

\section{Real Estate Portfolio Performance}

The average return, standard deviation, Sharpe ratio, Sortino ratio and the ranks attached to these risk adjusted performance measures are reported in Table 5 calculated using all available data, from the $3^{\text {rd }}$ quarter 1986 to the $3^{\text {rd }}$ quarter 2009 (93 quarters). These statistics are calculated for risk free rate adjusted returns for various portfolios consisting of the real estate assets. The first group of three portfolios (columns 2 to 4) consist of $100 \%$ investment in commercial real estate (CP), residential real estate (RP) and listed REITs (LR). The second group of real estate assets (columns 5 to 7) consists of three portfolios of equally weighted pairs of the real estate assets with $50 \%$ investment in both $\mathrm{CP}$ and $\mathrm{RP}, 50 \%$ investment in both $\mathrm{CP}$ and $\mathrm{LR}, 50 \%$ investment in both $\mathrm{RP}$ and LR. The final portfolio (column 8) is an equally weighted portfolio of all three real estate classes with $1 / 3$ investment in each of the three real estate asset classes (CP, RP and LR). The investment weighting used in portfolio creation is listed in the first section of the table for each of the combinations and the matching statistics for these combinations are then reported in the matching columns in the lower section of the table.

The relatively strong performance of residential-real estate is highlighted in Table 5, with $100 \%$ investment in RP ranking highest in terms of mean return, Sharpe ratio and Sortino ratio. The next most preferred alternative is an equal investment in RP and CP. The poor relative performance of REITs is also quite clear from the rankings reported in this Table. 


\begin{tabular}{|c|c|c|c|c|c|c|c|}
\hline & $C P$ & $R P$ & $L R$ & $C P / R P$ & $C P / L R$ & $R P / L R$ & $\begin{array}{c}C P / R P / \\
L R \\
\end{array}$ \\
\hline $\begin{array}{l}\text { Asset weight } \\
\text { Com } \\
\text { Res } \\
\text { REIT }\end{array}$ & 1.0000 & 1.0000 & 1.0000 & $\begin{array}{l}0.5000 \\
0.5000\end{array}$ & $\begin{array}{l}0.5000 \\
0.5000\end{array}$ & $\begin{array}{l}0.5000 \\
0.5000 \\
\end{array}$ & $\begin{array}{l}0.3333 \\
0.3333 \\
0.3333 \\
\end{array}$ \\
\hline $\begin{array}{l}\text { Panel } A\left(R_{\mathrm{p}}\right) \\
\text { Mean } \\
\text { Std. dev. } \\
\text { Sharpe ratio } \\
\text { SR rank } \\
\text { Sortino ratio } \\
\text { StR rank } \\
\end{array}$ & $\begin{array}{c}0.0030 \\
0.0251 \\
0.1212 \\
5 \\
0.6093 \\
3 \\
\end{array}$ & $\begin{array}{c}0.0119 \\
0.0240 \\
0.4963 \\
1 \\
1.7462 \\
1 \\
\end{array}$ & $\begin{array}{c}0.0009 \\
0.0920 \\
0.0094 \\
7 \\
0.3831 \\
7 \\
\end{array}$ & $\begin{array}{c}0.0075 \\
0.0214 \\
0.3500 \\
2 \\
1.0389 \\
2 \\
\end{array}$ & $\begin{array}{c}0.0064 \\
0.0493 \\
0.1296 \\
4 \\
0.5096 \\
5\end{array}$ & $\begin{array}{c}0.0020 \\
0.0497 \\
0.0393 \\
6 \\
0.4346 \\
6\end{array}$ & $\begin{array}{c}0.0053 \\
0.0361 \\
0.1460 \\
3 \\
0.5575 \\
4\end{array}$ \\
\hline $\begin{array}{l}\text { Panel } B\left(R_{p}^{A}\right) \\
\text { Mean } \\
\text { Std. dev. } \\
\text { Sharpe ratio } \\
\text { SR rank } \\
\text { Sortino ratio } \\
\text { StR rank } \\
\end{array}$ & $\begin{array}{c}0.0033 \\
0.0613 \\
0.0544 \\
3 \\
0.5422 \\
3 \\
\end{array}$ & $\begin{array}{c}0.0130 \\
0.0384 \\
0.3388 \\
1 \\
1.1054 \\
1\end{array}$ & $\begin{array}{c}-0.0157 \\
0.0676 \\
-0.2329 \\
7 \\
0.2803 \\
7\end{array}$ & $\begin{array}{c}0.0082 \\
0.0381 \\
0.2145 \\
2 \\
0.7757 \\
2\end{array}$ & $\begin{array}{c}-0.0014 \\
0.0399 \\
-0.0343 \\
5 \\
0.4559 \\
5\end{array}$ & $\begin{array}{c}-0.0062 \\
0.0514 \\
-0.1206 \\
6 \\
0.3714 \\
6\end{array}$ & $\begin{array}{c}0.0002 \\
0.0379 \\
0.0053 \\
4 \\
0.5030 \\
4\end{array}$ \\
\hline
\end{tabular}

Note: This Table reports various measures of performance for seven portfolios including mean and standard deviation (Std.dev.) of return in excess of the risk free rate, Sharpe ratio and Sortino ratio. The rank for the Sharpe ratio (SR rank) and the Sortino ratio (StR rank) are also reported below the ratio. Results from analysis using unadjusted returns are reported in Panel $A$ and results based on adjusted returns (unsmoothed direct real estate returns and hedged REIT returns) are reported in Panel B. Portfolio weighting is reported for commercial real estate (Com), residential real estate (Res) and REITSs (REIT) in the second row of the Table with $100 \%$ investment in commercial real estate (CP), 100\% investment in residential real estate (RP), 100\% investment in Australian REITs (LR), 50\% investment in both $\mathrm{CP}$ and $\mathrm{RP}$ (CP/RP), $50 \%$ investment in both $\mathrm{CP}$ and $L R$ (CP/LR), 50\% investment in both RP and $L R$ (RP/LR) and $1 / 3$ investment in each of the three real estate asset classes (CP/RP/LR).

\section{Comparative Real Estate Portfolio Performance for the Full Period (93 quarters from $1986 q 3$ to $2009 q 3$ ) \\ Source: Authors \\ Table 5}

To gain some insight into the stability of these results, the Sharpe ratio and the Sortino ratio are reported in Table 6 for two sub-periods, the $3^{\text {rd }}$ quarter 1986 to the 1 st quarter 1998 (47 quarters) and the $2^{\text {nd }}$ quarter 1998 to the $3^{\text {rd }}$ quarter 2009 (46 quarters). These risk adjusted measure rankings are not sensitive to adjustments like unsmoothing of the direct investment returns or using hedged REIT returns as the relative performance based rankings reported in Table 6 for the adjusted data, $R_{p}^{A}-R_{f}$, are faitly consistent with those reported for the unadjusted data, $R_{p j}-R_{f}$. Table 6 provides further support for the relatively strong performance of residential real estate over different time sub-periods. Both the Sharpe and Sortino ratio analysis show residential real estate performance as the preferred asset class. A $100 \%$ investment in REITs generally ranks worst in terms of risk adjusted performance in both Table 5 and Table 6 .

Markowitz optimal portfolios could be used in examining the performance of real estate based portfolios but there is a tendency for these portfolios to plunge into particular asset classes with the 
result that the optimal portfolio can be quite concentrated. As we wish to explore the impact of different types of real estate on portfolio performance, we choose equally weighted combinations of the three real estate asset classes in this section.

\begin{tabular}{|c|c|c|c|c|c|c|c|}
\hline & $C P$ & $R P$ & $L R$ & $C P / R P$ & $C P / L R$ & $R P / L R$ & $C P / R P / L R$ \\
\hline $\begin{array}{l}\text { Asset weight } \\
\text { Com } \\
\text { Res } \\
\text { REIT }\end{array}$ & 1.000 & 1.000 & 1.000 & $\begin{array}{l}0.500 \\
0.500\end{array}$ & $\begin{array}{l}0.500 \\
0.500\end{array}$ & $\begin{array}{l}0.500 \\
0.500 \\
\end{array}$ & $\begin{array}{l}0.333 \\
0.333 \\
0.333 \\
\end{array}$ \\
\hline $\begin{array}{l}\text { Sharpe ratio rank using } R_{p}-R_{f} \\
1986 \mathrm{q} 3-2009 \mathrm{q} 3 \\
1986 \mathrm{q} 3-1998 \mathrm{q} 1 \\
1998 \mathrm{q} 2-2009 \mathrm{q} 3\end{array}$ & $\begin{array}{l}5 \\
7 \\
3 \\
\end{array}$ & $\begin{array}{l}1 \\
1 \\
2 \\
\end{array}$ & $\begin{array}{l}7 \\
3 \\
7 \\
\end{array}$ & $\begin{array}{l}2 \\
5 \\
1 \\
\end{array}$ & $\begin{array}{l}4 \\
2 \\
5 \\
\end{array}$ & $\begin{array}{l}6 \\
6 \\
6 \\
\end{array}$ & $\begin{array}{l}3 \\
4 \\
4 \\
\end{array}$ \\
\hline $\begin{array}{l}\text { Sortino ratio rank using } R_{p} \text { and } \\
\text { reference return } R_{f} \\
1986 \mathrm{q} 3-2009 \mathrm{q} 3 \\
1986 \mathrm{q} 3-1998 \mathrm{q} 1 \\
1998 \mathrm{q} 2-2009 \mathrm{q} 3\end{array}$ & $\begin{array}{l}3 \\
3 \\
3 \\
\end{array}$ & $\begin{array}{l}1 \\
1 \\
1\end{array}$ & $\begin{array}{l}7 \\
7 \\
7\end{array}$ & $\begin{array}{l}2 \\
2 \\
2 \\
\end{array}$ & $\begin{array}{l}5 \\
5 \\
5 \\
\end{array}$ & $\begin{array}{l}6 \\
6 \\
6 \\
\end{array}$ & $\begin{array}{l}4 \\
4 \\
4 \\
\end{array}$ \\
\hline $\begin{array}{l}\text { Sharpe ratio rank using } R_{p}^{A}-R_{f} \\
1986 \mathrm{q} 3-2009 \mathrm{q}^{3} \\
1986 \mathrm{q} 3-1998 \mathrm{q} 1 \\
1998 \mathrm{q} 2-2009 \mathrm{q} 3\end{array}$ & $\begin{array}{l}3 \\
3 \\
3 \\
\end{array}$ & $\begin{array}{l}1 \\
1 \\
1\end{array}$ & $\begin{array}{l}7 \\
7 \\
7 \\
\end{array}$ & $\begin{array}{l}2 \\
2 \\
2 \\
\end{array}$ & $\begin{array}{l}5 \\
4 \\
5 \\
\end{array}$ & $\begin{array}{l}6 \\
6 \\
6 \\
\end{array}$ & $\begin{array}{l}4 \\
5 \\
4 \\
\end{array}$ \\
\hline $\begin{array}{l}\text { Sortino ratio rank using } R_{p}^{A} \text { and } \\
\text { reference roturn } R_{f} \\
1986 \mathrm{q} 3-2009 \mathrm{q} 3 \\
1986 \mathrm{q} 3-1998 \mathrm{q} 1 \\
1998 \mathrm{q} 2-2009 \mathrm{q} 3\end{array}$ & $\begin{array}{l}3 \\
3 \\
5 \\
\end{array}$ & $\begin{array}{l}1 \\
1 \\
1 \\
\end{array}$ & $\begin{array}{l}7 \\
7 \\
7 \\
\end{array}$ & $\begin{array}{l}2 \\
2 \\
2 \\
\end{array}$ & $\begin{array}{l}5 \\
5 \\
4 \\
\end{array}$ & $\begin{array}{l}6 \\
6 \\
6 \\
\end{array}$ & $\begin{array}{l}4 \\
4 \\
3 \\
\end{array}$ \\
\hline
\end{tabular}

Note: This Table reports the rank for the Sharpe ratios and the Sortino ratios for the full period (quarter 3 of 1986 to quarter 3 of 2009 ) and for sub periods, sub period one (quarter 3 of 1986 to quarter 1 of 1998) and for sub period two (quarter 2 of 1998 to quarter 3 of 2009). Results are reported for both unadjusted returns, $R_{p}$, and for adjusted returns, $R_{p}^{A}$, (unsmoothed direct real estate returns and hedged REIT returns). The portfolio weighting is reported in the second row of the Table with $100 \%$ investment in commercial real estate (CP), 100\% investment in residential real estate (RP), 100\% investment in Australian REITs (LR), 50\% investment in both CP and RP (CP/RP), 50\% investment in both $\mathrm{CP}$ and LR (CP/LR), 50\% investment in both RP and $L R(R P / L R)$ and $1 / 3$ investment in each of the three real estate asset classes (CP/RP/LR).

\section{Comparative Real Estate Portfolio Performance (1986q3 to $1998 \mathrm{q} 1$ and $1998 \mathrm{q} 2$ to $2009 \mathrm{q} 3$ ) \\ Source: Authors \\ Table 6}

Table 6 shows that for both the Sharpe and the Sortino ratios, a $100 \%$ direct investment in residential real estate generally ranks first amongst the alternatives, while a $100 \%$ investment in REITs is the worst performing of the real estate asset classes with a rank of 7 in virtually all cases. Equal investment in residential real estate and REITs also performs poorly, with a Sharpe and a Sortino ratio rank of 6 (see Table 5). These results for best and worst performing portfolios appear robust to choice of period used in analysis with little variation between the full and sub periods studied. 


\section{Impact of Real Estate Investment on Equity Portfolio Performance}

In this section we explore the impact on portfolio returns of combining the various real estate combinations described in the previous section with a well-diversified equity portfolio (SP). The results from analysis of real estate portfolio performance are reported in Table 7 for both the unadjusted and adjusted returns where it is assumed real estate accounts for $5 \%$ of the portfolio value following the institutional practices noted in the USA (Hudson-Wilson et al 2003).

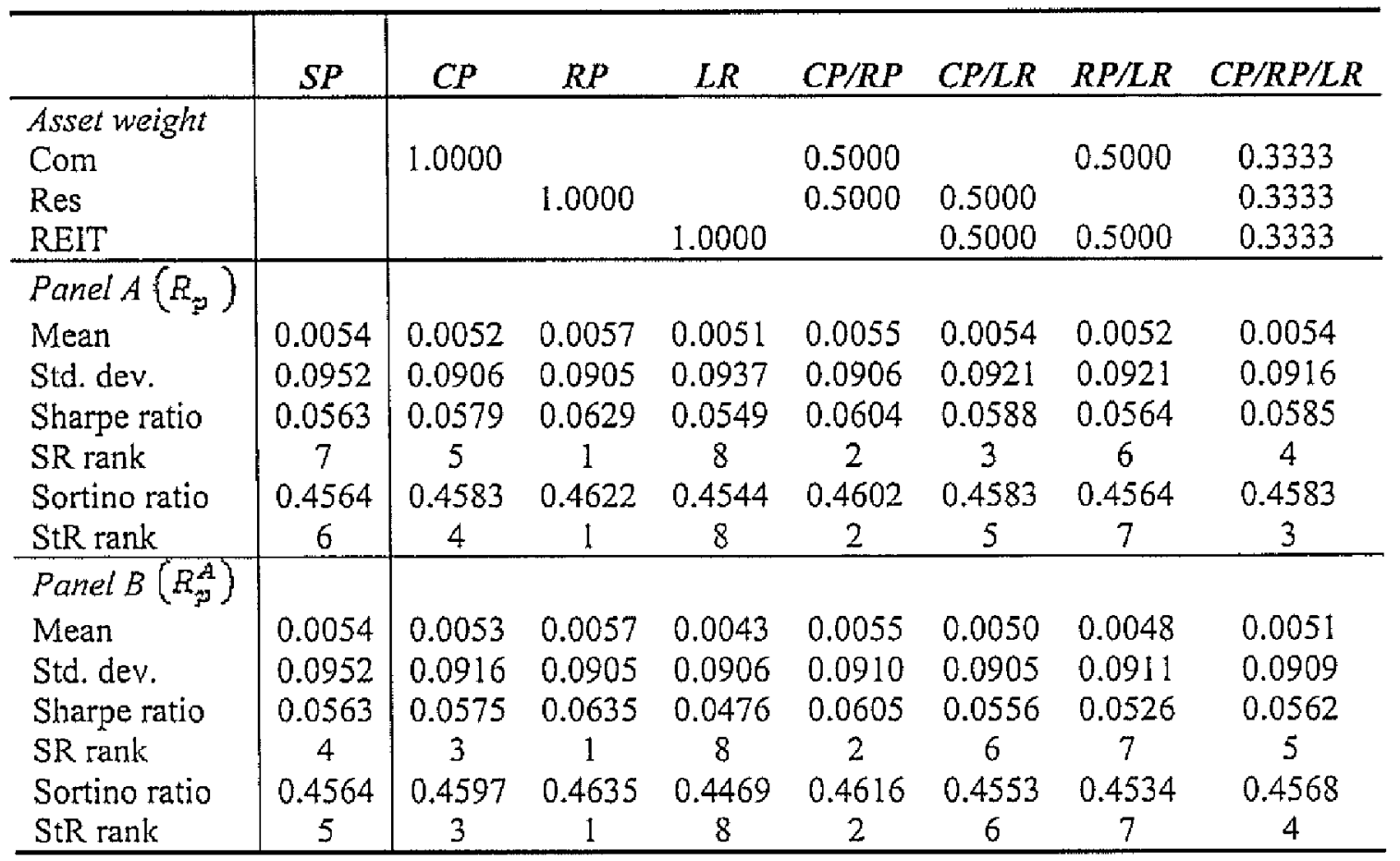

Note: This Table reports various measures of performance for seven portfolios including mean and standard deviation (Std.dev.) of return in excess of the risk free rate, Sharpe ratio and Sortino ratio. The rank for the Sharpe ratio (SR rank) and the Sortino ratio (StR rank) are also reported below the ratio. Results from analysis using unadjusted returns are reported in Panel $A$ and results based on adjusted returns (unsmoothed direct real estate returns and hedged REIT returns) are reported in Panel $\mathrm{B}$. The results for the share market are reported in the second column (SP). There is $95 \%$ investment in equities and $5 \%$ is allocated to the seven real estate portfolios set out in Table 5. Portfolio weighting is reported for commercial real estate (Com), residential real estate (Res) and REITSs (REIT) in the second row of the Table with $100 \%$ investment in commercial real estate (CP), $100 \%$ investment in residential real estate (RP), $100 \%$ investment in Australian REITs (LR), 50\% investment in both $\mathrm{CP}$ and $\mathrm{RP}$ (CP/RP), 50\% investment in both $\mathrm{CP}$ and $\mathrm{LR}$ (CP/LR), 50\% investment in both RP and LR (RP/LR) and 1/3 investment in each of the three real estate asset classes (CP/RP/LR).

\section{Comparative Share and Real Estate Portfolio Performance With 95\% Equity and 5\% Real Estate (1986q3 to 2009q3) \\ Source: Authors \\ Table 7}

The results reported in Table 8 show the impact on portfolio performance of increasing the proportion of portfolio value allocated to real estate to $10 \%$, consistent with UK and Australian institutional practice (APRA 2012, Blake et al 1999). As with Table 7 results are reported for both the unadjusted and adjusted returns. 


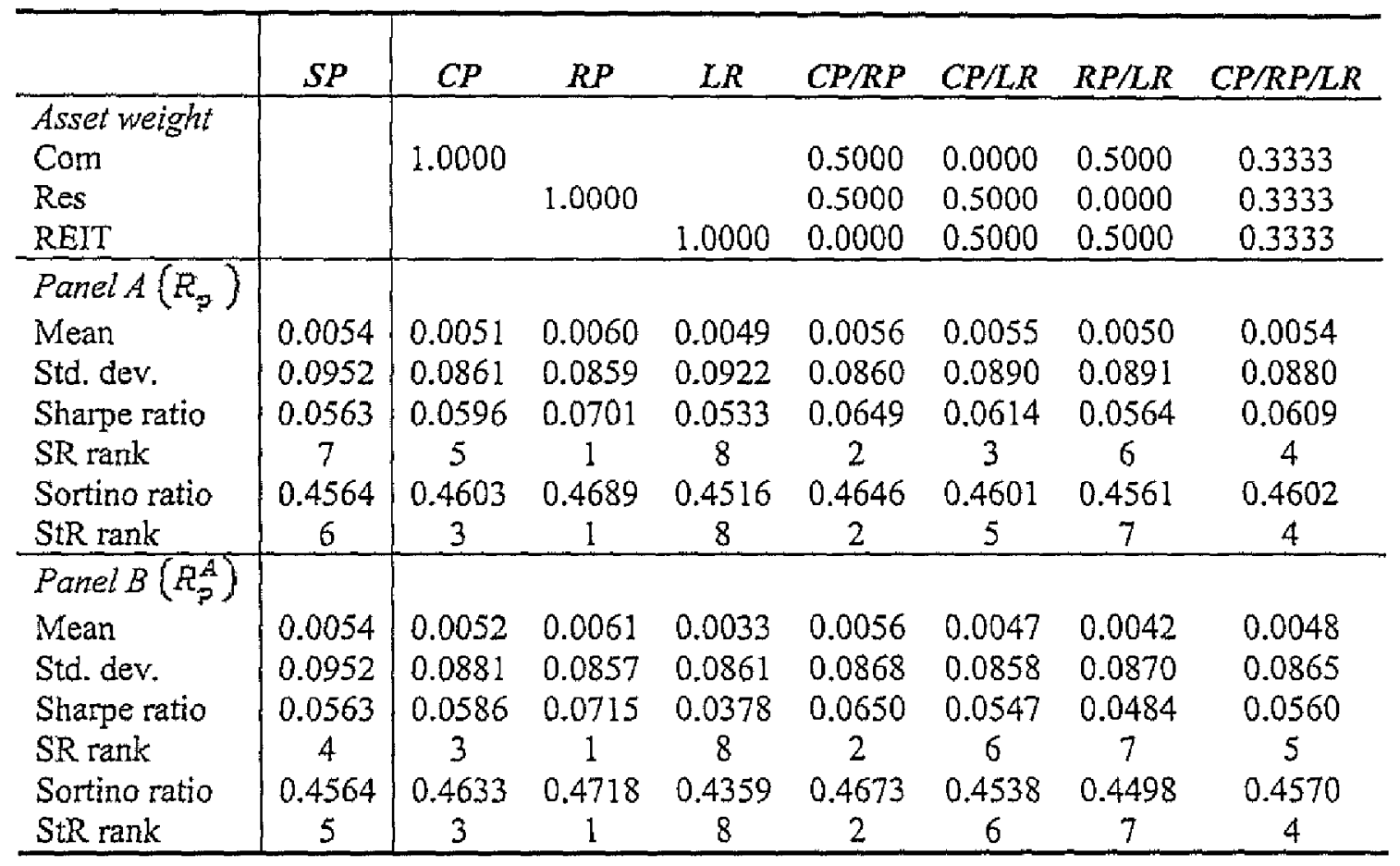

Note: This Table reports various measures of performance for seven portfolios including mean and standard deviation (Std.dev.) of return in excess of the risk free rate, Sharpe ratio and Sortino ratio. The rank for the Sharpe ratio (SR rank) and the Sortino ratio (StR rank) are also reported below the ratio. Results from analysis using unadjusted returns are reported in Panel A and results based on adjusted returns (unsmoothed direct real estate returns and hedged REIT returns) are reported in Panel $\mathrm{B}$. The results for the share market are reported in the second column (SP). There is $90 \%$ investment in equities and $10 \%$ is allocated to the seven real estate portfolios set out in Table 5. Portfolio weighting is reported for commercial real estate (Com), residential real estate (Res) and REITSs (REIT) in the second row of the Table with $100 \%$ investment in commercial real estate (CP), $100 \%$ investment in residential real estate (RP), $100 \%$ investment in Australian REITs (LR), 50\% investment in both CP and RP (CP/RP), 50\% investment in both $\mathrm{CP}$ and $\mathrm{LR}$ (CP/LR), 50\% investment in both RP and LR (RP/LR) and $1 / 3$ investment in each of the three real estate asset classes (CP/RP/LR).

\section{Comparative Share and Real Estate Portfolio Performance With $90 \%$ Equity and 10\% Real Estate (1986q3 to 2009q3) Source: Authors \\ Table 8}

In both Tables 7 and 8 , the All Ordinaries share price index is used as a proxy for a well-diversified portfolio of shares. Portfolio proportions used in analysis consist of either $95 \%$ shares with $5 \%$ real estate or $90 \%$ shares with $10 \%$ real estate. While these allocations are arbitrary they avoid plunging into one or two assets classes, which is often observed with Markowitz optimal portfolios.

Sharpe ratios and Sortino ratios are reported in Table 9 for the full period, $3^{\text {rd }}$ quarter 1986 to $3^{\text {rd }}$ quarter 2009 , and sub periods, $3^{\text {rd }}$ quarter 1986 to $1^{\text {st }}$ quarter 1998 and $2^{\text {nd }}$ quarter 1998 to $3^{\text {rd }}$ quarter 2009. The combination of a diversified portfolio of shares and direct investment in residential real estate ranks first amongst the alternative combinations of shares and real estate portfolios. These results are also quite stable across the sub-periods, with little change in relative performance as the real estate allocation is increased from $5 \%$ to $10 \%$. The choice of adjusted (unsmoothed direct 
returns or hedged REIT returns) or unadjusted returns has little impact on relative performance evaluation and so only the results for the adjusted returns are reported here.

\begin{tabular}{|c|c|c|c|c|c|c|}
\hline & $S P$ & $C P$ & $R P$ & $L R$ & $M O P$ & $C P / R P / L R$ \\
\hline $\begin{array}{l}\text { Asset weight } \\
\text { Commercial } \\
\text { Residential } \\
\text { REIT } \\
\end{array}$ & & 1.0000 & 1.0000 & 1.0000 & $\begin{array}{l}0.0000 \\
0.0000 \\
0.0000\end{array}$ & $\begin{array}{l}0.3333 \\
0.3333 \\
0.3333 \\
\end{array}$ \\
\hline $\begin{array}{l}\text { Sharpe ratio with } \\
\text { adjusted returns } \\
1986 q 3-2009 q 3 \\
1986 q 3-1998 q 1 \\
1998 q 2-2009 q 3\end{array}$ & $\begin{array}{c}95 \% \\
\text { shares } \\
4 \\
3 \\
5\end{array}$ & $\begin{array}{c}5 \% \text { real } \\
\text { estate } \\
3 \\
6 \\
3\end{array}$ & $\begin{array}{l}1 \\
1 \\
1\end{array}$ & $\begin{array}{l}8 \\
8 \\
8\end{array}$ & $\begin{array}{l}7 \\
7 \\
7\end{array}$ & $\begin{array}{l}5 \\
5 \\
4\end{array}$ \\
\hline $\begin{array}{l}\text { Sortino ratio with } \\
\text { adjusted returns } \\
1986 \mathrm{q} 3-2009 \mathrm{q} 3 \\
1986 \mathrm{q} 3-1998 \mathrm{q} 1 \\
1998 \mathrm{q} 2-2009 \mathrm{q} 3\end{array}$ & $\begin{array}{c}95 \% \\
\text { shares } \\
5 \\
3 \\
4\end{array}$ & $\begin{array}{l}5 \% \text { real } \\
\text { estate } \\
3 \\
4 \\
3\end{array}$ & $\begin{array}{l}1 \\
1 \\
1\end{array}$ & $\begin{array}{l}8 \\
8 \\
8\end{array}$ & $\begin{array}{l}7 \\
7 \\
7\end{array}$ & $\begin{array}{l}4 \\
5 \\
5\end{array}$ \\
\hline $\begin{array}{l}\text { Sharpe ratio with } \\
\text { adjusted returns } \\
1986 q 3-2009 q 3 \\
1986 q 3-1998 q 1 \\
1998 q 2-2009 q 3\end{array}$ & $\begin{array}{c}90 \% \\
\text { shares } \\
4 \\
3 \\
5\end{array}$ & $\begin{array}{l}10 \% \text { real } \\
\text { estate } \\
3 \\
6 \\
3\end{array}$ & $\begin{array}{l}1 \\
1 \\
1\end{array}$ & $\begin{array}{l}8 \\
8 \\
8\end{array}$ & $\begin{array}{l}7 \\
7 \\
7\end{array}$ & $\begin{array}{l}5 \\
5 \\
4\end{array}$ \\
\hline $\begin{array}{l}\text { Sortino ratio with } \\
\text { adjusted returns } \\
1986 \mathrm{q} 3-2009 \mathrm{q} 3 \\
1986 \mathrm{q} 3-1998 \mathrm{q} 1 \\
1998 \mathrm{q} 2-2009 \mathrm{q} 3\end{array}$ & $\begin{array}{c}90 \% \\
\text { shares } \\
5 \\
4 \\
4 \\
\end{array}$ & $\begin{array}{l}10 \% \text { real } \\
\text { estate } \\
3 \\
3 \\
3\end{array}$ & $\begin{array}{l}1 \\
1 \\
1\end{array}$ & $\begin{array}{l}8 \\
8 \\
8\end{array}$ & $\begin{array}{l}7 \\
7 \\
7\end{array}$ & $\begin{array}{l}4 \\
5 \\
5\end{array}$ \\
\hline
\end{tabular}

Note: This Table reports the rank for the Sharpe ratios and the Sortino ratios for the full period (quarter 3 of 1986 to quarter 3 of 2009) and for sub periods, sub period one (quarter 3 of 1986 to quarter 1 of 1998) and for sub period two (quarter 2 of 1998 to quarter 3 of 2009). Results are reported for portfolios of equity and real estate using both unadjusted returns, $R_{p}$, and for adjusted returns, $R_{p}^{A}$, (unsmoothed direct real estate returns and hedged REIT returns). The equity proportion is reported in column 2 and the real estate proportion in column 3. The real estate portfolio weighting is reported in the second row of the Table with $100 \%$ investment in commercial real estate (CP), $100 \%$ investment in residential real estate (RP), 100\% investment in Australian REITs (LR), $50 \%$ investment in both CP and RP (CP/RP), 50\% investment in both CP and LR (CP/LR), 50\% investment in both RP and LR (RP/LR) and 1/3 investment in each of the three real estate asset classes (CP/RP/LR).

\section{Comparative Share and Real Estate Portfolio Performance Using Sharpe and Sortino Ratios for the Full Period and Sub Periods, $1986 \mathrm{q} 3$ to $1998 \mathrm{q} 1$ and $1998 \mathrm{q} 2$ to $2009 \mathrm{q} 3$ \\ Source: Authors \\ Table 9}




\section{Markowitz Optimal Weightings}

Arbitrary weighting schemes are used in the analysis reported above in order to ensure that the chosen portfolios were reasonably well diversified. In this section we briefly explore the impact of using Markowitz optimal portfolio weightings for the shares and the three real estate asset classes used in this study. Given the difficulty of short-selling real property we impose short-selling constraints on the portfolio weights. We calculate the optimal weights for the full period using various combinations of equity returns and adjusted or unadjusted real estate returns that achieve the equity portfolio return of 0.0251 per quarter.

\begin{tabular}{l|cccccc}
\hline & CP & RP & LR & Rallord & $\begin{array}{c}\text { Portfolio } \\
\text { Mean }\end{array}$ & $\begin{array}{c}\text { Portfolio } \\
\text { Variance }\end{array}$ \\
\hline Panel A, Unadj returns & & & & & & \\
optimal & 0.71 & 0.26 & 0.01 & 0.03 & 0.0251 & 0.0004 \\
at least 50\% equity & 0.37 & 0.13 & 0.00 & 0.50 & 0.0251 & 0.0023 \\
at least 60\% equity & 0.30 & 0.10 & 0.00 & 0.60 & 0.0251 & 0.0033 \\
at least 70\% equity & 0.22 & 0.08 & 0.00 & 0.70 & 0.0251 & 0.0044 \\
at least 80\% equity & 0.15 & 0.05 & 0.00 & 0.80 & 0.0251 & 0.0057 \\
at least 90\% equity & 0.07 & 0.03 & 0.00 & 0.90 & 0.0251 & 0.0071 \\
$100 \%$ equity & & & & 1.00 & 0.0251 & 0.0089 \\
Panel B, Adj CP and RP & & & & & & \\
optimal & 0.53 & 0.26 & 0.20 & 0.00 & 0.0251 & 0.0020 \\
at least 50\% equity & 0.40 & 0.10 & 0.00 & 0.50 & 0.0251 & 0.0035 \\
at least 60\% equity & 0.32 & 0.08 & 0.00 & 0.60 & 0.0251 & 0.0042 \\
at least 70\% equity & 0.24 & 0.06 & 0.00 & 0.70 & 0.0251 & 0.0051 \\
at least $80 \%$ equity & 0.16 & 0.04 & 0.00 & 0.80 & 0.0251 & 0.0062 \\
at least 90\% equity & 0.08 & 0.02 & 0.00 & 0.90 & 0.0251 & 0.0074 \\
100\% equity & & & & 1.00 & 0.0251 & 0.0089 \\
Panel C, Adj CP, RP & & & & & & \\
and LR & & & & & & \\
optimal & 0.14 & 0.58 & 0.20 & 0.09 & 0.0251 & 0.0009 \\
at least 50\% equity & 0.00 & 0.37 & 0.13 & 0.50 & 0.0251 & 0.0024 \\
at least 60\% equity & 0.00 & 0.29 & 0.11 & 0.60 & 0.0251 & 0.0033 \\
at least 70\% equity & 0.00 & 0.22 & 0.08 & 0.70 & 0.0251 & 0.0043 \\
at least $80 \%$ equity & 0.00 & 0.15 & 0.05 & 0.80 & 0.0251 & 0.0056 \\
at least 90\% equity & 0.00 & 0.07 & 0.03 & 0.90 & 0.0251 & 0.0071 \\
$100 \%$ equity & & & & 1.00 & 0.0251 & 0.0089 \\
\hline
\end{tabular}

Note: This Table contains short-selling constrained Markowitz optimal portfolio weights for the full study period using various combinations of equity returns and adjusted or unadjusted real estate retums that achieve the $100 \%$ equity portfolio retum of 0.0251 per quarter. There are three sets of results reported in Panels A, B and C. Panel A refers to results for unadjusted returns, Panel $B$ refers to results for unsmoothed direct investment returns and unhedged REIT returns and Panel $\mathrm{C}$ refers to unsmoothed direct investment returns and hedged REIT returns. The short-selling constrained Markowitz optimal portfolio is reported along with a set of short-selling constrained Markowitz optimal portfolios with minimum equity positions of $50 \%$ through to $90 \%$. The all equity portfolio results are reported for reference. The portfolio weights are reported in column 2 for commercial property (CP), column 3 for residential property (RP), column 4 for REITs (LR) and column 5 for equity (SP), with the mean portfolio return reported in in column 6 and the portfolio variance reported in column 7 .

\section{Markowitz Optimal Portfolios That Earn the Same Return as an All Equity Portfolio \\ Source: Authors}

Table 10 
There are three sets of results reported in Panels $\mathrm{A}, \mathrm{B}$ and $\mathrm{C}$ of Table 10. Panel $\mathrm{A}$ refers to results for unadjusted returns, Panel B refers to results for unsmoothed direct investment returns and unhedged REIT returns and Panel $\mathrm{C}$ refers to unsmoothed direct investment returns and hedged REIT returns. The short-selling constrained Markowitz optimal portfolio is reported along with a set of short-selling constrained Markowitz optimal portfolios with minimum equity positions of $50 \%$ through to $90 \%$. The all equity portfolio results are reported for reference.

The first set of results is based on unadjusted real estate returns. The portfolio with zero constraint on equity loads heavily on commercial property with a weighting of $71 \%$, with $26 \%$ allocated to residential property and around $3 \%$ to equity. This is clearly of not much interest to an equity portfolio manager, though as the level of equity is constrained from $50 \%$ through to $90 \%$ the preference for direct investment in real estate remains with a preference for commercial real estate. The loading on REITs is generally zero in this analysis.

As discussed above, there are problems with using unadjusted returns in this sort of analysis and so we repeat this analysis in Panel B using unsmoothed commercial real estate returns and unsmoothed residential real estate returns but leaving REIT returns unadjusted. It is interesting to note the shortselling constrained Markowitz optimal portfolio which has no exposure to equity at all though it does include a $20 \%$ exposure to REITs. The remainder of the investment is allocated to commercial real estate and residential real estate with the greater loading on commercial property investment. Once equity investment limits are set to $50 \%$ through $90 \%$ the weighting attached to REITs becomes zero. This result is consistent with the level of correlation that exists between these two classes of equity investment.

In Panel $\mathrm{C}$, the direct real estate investment returns are unsmoothed and the REIT returns orthogonalised and these adjusted returns are used in portfolio construction. In this case the Markowitz optimal portfolios tend to load onto unsmoothed residential real estate with the remainder invested in REITs. Commercial real estate is not included in the optimal portfolios once equity is constrained to $50 \%$ or more of the portfolio assets.

\section{DISCUSSION AND CONCLUSION}

This paper uses mean, standard deviation, Sharpe ratios and Sortino ratios in an analysis of the comparative performance of portfolios of direct residential real estate investment, direct commercial real estate investment and investment in REITs as well as in analysis of the impact of combining real estate with a well-diversified share portfolio. It is found that combinations of shares and direct real estate investment are generally preferred to shares alone and combinations of shares and direct real estate investments tend to be preferred to combinations of shares and REITs even after adjustment for equity effects.

The best performing portfolios in terms of the Sharpe ratio and the Sortino ratio consist of shares and direct investment in residential real estate with this combination generally ranking first amongst the alternative combinations of shares and real estate portfolios. This result is also quite stable across the sub-periods 1985-1997 and 1997-2009. It would appear that residential real estate investment offers valuable diversification potential. Yet, we acknowledge that our residential real estate index for Australia may not provide a particularly representative measure of the performance of the many individual residential real estate markets that exist around Australia. Importantly, there is no recognised securitised residential real estate product (either listed or unlisted) on offer in Australia at present. Thus, an institution considering investment in residential real estate would need to physically acquire a portfolio of individual residential dwellings in order to capture the returns that we note in this analysis. 
We also find that combining commercial real estate with a well-diversified portfolio of shares is preferred to shares alone over the full period of the study though there is some variation across the sub-periods. A number of large Australian institutions include direct commercial real estate investment as part of their investment portfolio and the results reported above provide some support for this investment decision. Again, our analysis is based on an Australia wide portfolio of commercial properties though there are a number of mutual funds and trusts that specialise in commercial property investment and so it is likely that these results could be replicated, at least to some extent, in practise.

We also explore the real estate investment decision within a short-selling constrained Markowitz optimal portfolio consisting of equity and the three classes of real estate. This analysis applied both to adjusted and unadjusted returns to gain some sense of the impact of return adjustment for unsmooth direct investment returns and for orthogonalising REIT returns with respect to the equity market. While commercial real estate is preferred when using unadjusted returns, residential real estate is preferred when using adjusted returns. Nevertheless, the preference for direct investment in either commercial or residential real estate is preferred over REITS.

It is important to note the features of the real estate asset classes and the nature of the data relied upon in interpreting these results. While REITS perform poorly when compared with commercial real estate and residential real estate, this asset class offers investors the ability to buy and sell units in the REIT on an organised exchange. Marketability of these exchange traded units is undoubtedly a valuable characteristic for an active investor or for an investor with a short investment horizon. The residential real estate series reflects the performance that might be achieved from a highly diversified residential real estate portfolio though we acknowledge that this may be costly to replicate in practise. There are benefits to be had from investing in real estate though the form of investment, direct or indirect, and the choice of real estate class, commercial or residential, could have implications for portfolio performance.

\section{REFERENCES}

Abelson, P, Roselyne, J, Milunovich, G, and Chung, D 2005, 'Explaining house prices in Australia: 1970 to 2003', Economic Record Vol. 81, S96-\$103.

Australian Prudential Regulatory Authority 2011, Statistics, Annual Superanmiation Bulletin, June 2011 , accessed 12 June 2012, http://www.apra.gov.au/Super/Pubications/Pages/annualsuperannuation-publication.aspx.

Blake, D, Lehmann, B, and Timmermann, A 1999, 'Asset allocation dynamics and pension fund performance', Journal of Business, Vol. 72, pp. 429-461.

Bodman, $\mathrm{P}$ and Crosby, $\mathrm{N} 2003$, How far to fall? bubbles in major city house prices in Australia, University of Queensland, School of Economics, Working Paper.

Brounen, D and Eichholtz, P 2003, 'Property, common stock, and property shares', Journal of Portfolio Management, Vol. 30, pp. 129-137.

Byme, $P$ and Lee, $S 1995$, 'Is there a place for property in the multi-asset portfolio?', Journal of Property Finance, Vol. 6, pp. 60-83.

Chaudhry, A and Jolnson, $H$ 2008, 'The efficiency of the Sortino ratio and other benchmarked performance measures under skewed return distributions', Australian Journal of Management, Vol. 32, pp. 485-502.

Chiang, $K$ and Lee, M-L 2007, 'Spanning tests on public and private real estate', Joumal of Real Estate Portfolio Management, Vol. 13, pp. 7-15.

Cho, $\mathrm{H}$, Kawaguchi, $\mathrm{Y}$ and Shilling, J 2003, 'In snoothing commercial property returns: a revision to the Fisher-Geltner-Webb's unsmoothing methodology', Journal of Real Estate Finance and Economics, Vol. 27, pp. 393-405. 
Clayton, J and MacKinnon, G 2001, 'The time-varying nature of the link between REIT, real estate and financial asset returns', Journal of Real Estate Portfolio Management, Vol. 7, pp. 43-54.

Geltner, D and Goetzmann, W 2000, 'Two decades of commercial property returns: a repeatedmeasures regression-based version of the NCREIF index', Journal of Real Estate Finance and Economics, Vol. 21, pp. 5-21.

Georgiev, G, Bhaswar, G, and Kunkel, T 2003, 'Benefits of real estate investment', Joumal of Portfolio Management, Vol. 30.

Giliberto, M 1993, 'Measuring real estate returns: the hedged REIT index', Journal of Portfolio Management, Vol. 19, pp. 94-99.

Giliberto, M 2003, 'Assessing real estate volatility', Joumal of Portfolio Management, Vol. 30 , pp. $122-128$

Higgins, D 2007, Placing commercial property in the Australian capital market, RICS Research Paper Series 7, London.

Higgins, D and $\mathrm{Ng}, \mathrm{B} 2009$, 'Australian securitised property funds: an examination of their riskadjusted performance', Journal of Property Investment and Finance, Vol. 27, pp. 404-412.

Hudson-Wilson, S, Fabozzi, F and Gordon, J 2003, 'Why real estate?', Journal of Portfolio Management, Vol. 30, pp. 12-25.

Jud, G, Wingler, T and Winkler, D 2006, 'Single-family housing and wealth portfolios', Journal of Real Estate Portfolio Management, Vol. 12, pp. 13-22.

Lee, C 2008, 'Housing in Australia as a portfolio investment', International Joumal of Housing Markets and Analysis, Vol. 1, pp. 352-361.

Lee, M-L, Lee, M-T and Chiang, K 2007, 'Structural breaks and cross-continental real estate securities diversification: evidence from spanning tests', Pacific Rim Property Research Joumal, Vol. 13, pp. 510-535.

Lee, $\mathrm{S}$ and Stevenson, S 2005, 'The case for REITs in the mixed-asset portfolio in the short and long run', Journal of Real Estate Portfolio Management, Vol. 11, pp. 55-80.

MacGregor, B and Nanthakumaran, N 1992, 'The allocation to property in the multi-asset portfolio: the evidence and theory reconsidered', Journal of Property Research, Vol. 9, pp. 5-32.

Masron, $\mathrm{T}$ and Fereidouni, $\mathrm{H}$ 2010, 'Performance and diversification benefits of housing investment', International Journal of Economics and Finance, Vol. 2, pp. 7-11.

Newell, G, and MacFarlane, J 1996, 'Risk estimation and appraisal-smoothing in UK property returns', Journal of Property Research, Vol. 13, pp. 1-12.

Newell, G, Peng, $\mathrm{H}$ and de Francesco, A 2011, "The performance of unlisted infrastructure in investment portfolios', Journal of Property Research, Vol. 28, pp. 59-74.

Sortino, F and Price, L 1994, 'Performance measurement in a downside risk framework', Journal of Investing, Vol. 3, pp. 50-58.

\section{ACKNOWLEDGMENTS}

We thank the Australian Centre for Financial Studies, previously the Melbourne Centre for Financial Studies, for financial support though grant number 12, awarded in 2009.

\section{Email contact: Richard.Heaney@urya.edu.au}

